\title{
Public Procurement for the Circular Economy: a Comparative Study of Sweden and Spain
}

\author{
Leticia Fuertes Giné ${ }^{1,2}$ (D) Emanuela Vanacore ${ }^{2}$ (D) Agnieszka D. Hunka²
}

Received: 4 August 2021 / Accepted: 10 January 2022 /Published online: 18 January 2022

(C) The Author(s) 2022

\begin{abstract}
This article examines the relationship between circular economy and public procurement by regarding green procurement as an enabler for the transition from sustainable to circular public procurement. Considering the different green procurement uptakes under the common legal framework of the European Union, and particularly, the contrasting practice results of Spain and Sweden and the opposed legal configuration of their procurement Acts, a comparative law study of the exclusion of suppliers, awarding criteria and special conditions of performance's Articles is conducted.
\end{abstract}

Keywords Public procurement · Green procurement · Circular economy · Circular procurement $\cdot$ Sustainability

\section{Introduction}

In recent years, a shift towards a circular economy (CE) has brought forth promises to decouple economic growth from environmental degradation. Such a transition involves a change from linear (cradle-to-grave) to circular flows (reuse, remanufacture, recycle), and practitioners and academics alike, embrace $\mathrm{CE}$ as a technologically feasible way to achieve long-term sustainability [1].

The notion has also been hailed by decision-makers, especially the European Commission, as a way to reduce $\mathrm{CO}_{2}$ emissions and foster economic growth [2]. This highlights the role of institutional actors in stimulating sustainable development through public procurement [3]. Namely, green public procurement (GPP) has been recognized by European institutions as a

Agnieszka D. Hunka

agnieszka.hunka@ri.se

Leticia Fuertes Giné

fuertesgine@gmail.com

Emanuela Vanacore

emanuela.vanacore@ri.se

1 Administrative Law Department, University of Zaragoza, calle Pedro Cerbuna 12, 50009 Zaragoza, Spain

2 Sustainable Business Unit, RISE Research Institutes of Sweden AB, Lindholmspiren 3A, 41756 Gothenburg, Sweden 
tool to support the transition towards CE [4]. GPP can be understood as the procurement of goods and services with a reduced environmental impact throughout their life cycle. ${ }^{1}$

Despite this explicit connection between GPP and CE, recent studies show that their integration might not be seamless yet. Both the scholarly and the practical gains for a circular transition through GPP remain fragmented. As a case-in-point, studies regarding circularity and sustainability indicators list between 50 and 300 indicators depending on their scope and source [5-9]. On the one hand, this opens a plethora of possibilities to apply CE indicators as selection criteria in procurements. On the other hand, few indicators described in the literature have been actually applied or are robust enough to benchmark procurement cases.

The interrelation between GPP and circular public procurement (CPP) shares a similar fate. The European Institutions distinguish them as two related, but separate practices in terms of their respective definitions, principles, objectives and execution [10]. However, GPP and CPP are carried out identically; by establishing certain environmental criteria in the tendering process [11], in compliance with Directive 2014/24/EU (the Directive), as the European legal umbrella framework, and with each Member State's applicable procurement legislation.

Moreover, the uptake of GPP is polarized across European countries [12, 13]. Even though this could be attributable to the recommendation of tailoring $\mathrm{CE}$ implementation strategies to each individual country due to their different socio-economic conditions [14], the extent of such dispersion can be striking from a legal perspective, since all European nations' procurement legislation derives from the Directive, to at least some extent [15].

Against this background, the objective of this paper is to determine whether any legal factors have influenced the referred fracture between GPP, circularity, and the uptake of the former in Europe. Hence, and for the purpose of conducting this study from a multilevel legislative context that comprises the unified European standpoint, in addition to suggestions on how procurement law can contribute to the CE transition, we conducted a comparative analysis of two Member States' Procurement Acts and their corresponding environmental considerations, i.e. Sweden and Spain.

The paper is structured as follows: the next section provides a background on the connection between GPP and CE, and the Directive's transposition process into Member States' legislation. The methodology section addresses, firstly, the assessment of the choice of Sweden and Spain's Procurement Acts and outlines the specific steps of the comparative analysis. Afterwards, we present the results, which comprise the main characteristics of Sweden and Spain's Procurement Acts, as well as a selection of their most environmentally distinctive and relevant Articles. Finally, the conclusion section discusses the main implications of the analysis, offering guidelines to policy makers.

\section{Theoretical Background}

\section{A. Circular Economy and GPP}

A leading role of the public sector has been postulated in the European Union Communication 'A new circular economy action plan for a cleaner and more competitive Europe' [10].

\footnotetext{
1 The European Commission's Public procurement for a circular economy. Good practice and guidance [29] brochure takes on the GPP definition provided in Commission 'Public procurement for a better environment' COM (2008) 400 final, which established that GPP is:

'...a process whereby public authorities seek to procure goods, services and works with a reduced environmental impact throughout their life cycle when compared to goods, services and works with the same primary function that would otherwise be procured.'
} 
In the document, the European Commission (EC) refers to GPP as a tool to support the CE transition. Moreover, the public sector's size and purchase power, which, for instance, in the European Union accounts to 14\% of Gross Domestic Product (GDP) (around two trillion euros per year) $[3,16-18],{ }^{2}$ make it a pivotal trigger in the circular transition.

Two main ideas can be inferred from this positive outlook that GPP offers for CE. Initially, it can be deduced that circular elements are already being realized to some extent through the existing mechanisms of GPP $[11,19]$. The most common mechanism deployed to fulfil CE objectives is the inclusion of GPP-based circular criteria $[11]^{3}$ in a procurement process [20]. Subsequently, the fulfilment of CPP via GPP can blur the lines between the two practices. Kristensen et al. [21] stated that the majority of articulated CPP practices are GPP practices 'in disguise', as these practices have not inherently changed but are presented as CPP.

Nonetheless, GPP is believed to be able to supply 'circular quick fixes' without altering the existing procurement procedures and their current (legal) configuration [22], and this strategy may be considered the simplest way or a first phase of buying in a circular manner [20]. Thus, for the purposes of this paper, we adopted this particular focus. Thereby, the references to GPP in the forthcoming sections are regarded in the sense of a mechanism fostering circularity and aiming to accomplish a transition to CPP.

\section{B. Motivation for the Study: The Directive's Transposition Process and its Impact on the GPP Uptake}

Among the initiatives of 'A new circular economy action plan' Communication, the EC proposed to accommodate minimum mandatory GPP criteria and targets in sectoral legislation, and phase in compulsory reporting to monitor GPP compliance, on the basis that the current voluntary approach is limited [4].

The acknowledgement of the reduced impact of voluntary GPP is arguably contradictory with the legal formula designated for this procedure, which is traditionally the holder of a discretionary character. The establishment of optional environmental considerations was firstly introduced by the repealed Directive 2004/18/EC [23] and is still in force in the Directive 2014/24/EU, which albeit it advocates in favour of mandatory objectives in sector-specific legislation, it finds inappropriate to set general compulsory requirements for environmental procurement, due to the 'important differences between individual sectors and markets' [24]. ${ }^{4}$

From a legal perspective, one of the most distinctive features of a directive is that it is binding, for each Member State to which it is addressed, as to the result to be achieved, but each national authority can choose which forms and methods are the most appropriate to achieve such results. The scope of this fundamental European rule could be categorized as rather holistic, given that it enables national authorities to freely transpose a directive as long as the aim is to fulfil the Directive's purposes [15].

\footnotetext{
${ }^{2}$ Furthermore, in 2019, in Sweden this number constituted approximately one-sixth of its gross domestic product excluding VAT-which amounted to $€ 73$ billion) and Spain estimated a total of inversion of a $9,6 \%$ of its gross domestic product, constituting a 23,4\% of Spain's public expenditure.

${ }^{3}$ For instance, Alhola K. et al. [14] identify different sets of circular criteria depending on several circular business models. Namely: requiring renewable energy systems or materials, ensuring a prolonged product life through maintenance, repair, and design for durability, demanding improved efficiency of a product, accepting remanufactured/recycled components or materials, etc.

4 Whereas 95.
} 
In this light, and despite the Directive's common ground for the transposition exercise carried out by Member States, studies performed on the European GPP uptake show that this practice is clearly fragmented [25]. Bouwer et al. [12] mapped the status of GPP across the European Union, identifying Austria, Denmark, Finland, Germany, Netherlands, Sweden, and the UK as the 'Green-7', while the rest of the Member States were classified as the 'Other-18'. A few years later, Renda et al. [13] found that Belgium, Denmark, Netherlands, and Sweden had a GPP percentage between $80 \%$ and $60 \%$, whereas the rest of European countries reported between $40 \%$ and 20\%; despite Member States' procurement legislation shares the same root, the level of dispersion in the GPP uptake can be questioned.

The interpretation of the referred data likely comprises a variety of concepts, including cultural or societal transformations and value shifts [26]. Nevertheless, since public procurement is a highly regulated field, it can be considered as a preeminent legal matter. Our research question is which legal factors - if any - have a significant impact on the scatteration of GPP across Europe. To answer this question, we have conducted a comparative analysis of two Member States' Procurement Acts and their corresponding environmental considerations, to attempt to provide a two-tier explanation addressing the Directive, as transposed by Sweden and Spain.

\section{Methodological Framework of Analysis}

\section{A. Context of Analysis}

The suitability assessment that determined why Spain and Sweden, among all European countries, were chosen for the comparative study was performed upon two legal criteria and one policy and management criterion. Initially, we considered the polarization degree of the GPP uptake between both nations. Sweden would be allocated within the top European GPP performers, while Spain has not traditionally stood out for leading a notable GPP practice $[12,13]$. Regarding the second legal barometer, we contemplated the extent to which comparing the Procurement Acts would produce the most contrasting results. In this sense, and as further detailed in the comparative analysis below, collating the Swedish Procurement Act (LOU) [27], ${ }^{5}$ with the Spanish Procurement Act (LCSP) $[28]^{6}$ provides an antagonistic perspective on the transposition technique-LOU strongly resembles the Directive and LCSP has preserved some Spanish legal specificities - and the environmental approach-LOU stands by a should rule or bör-regeln as opposed to LCSP, which adopted a transversal and compulsory inclusion of social/environmental criteria.

Finally, related to the organization and management of Sweden and Spain's institutions, we reviewed some indicators relevant to GPP stated in the European Commission's report 'A Comparative Overview of Public Administration and Characteristics and Performance in EU 28' [29] in which Sweden and Spain were ranked similarly. Both countries are rated within the second quintile of the overall strategic planning capacity, sustainable governance implementation capacity, quality of government capacity, and inter-ministerial coordination. Withal, Sweden and Spain scored only one point away in the strategic planning

\footnotetext{
${ }^{5}$ For the purposes of this paper, the review was based on the 2017 English language version provided by the Swedish Competition Authority.

6 There is no official English language version of this Act.
} 
capacity test. To this effect, GPP arises from the arrangement and convergence of the public authorities' economic volume and powerful sustainability message, requiring the coordination and confluence of the different administrations' wills and intents to truly achieve environmental goals. Hence, the coordination of different administrative levels, objectives, and economic resources makes GPP a strategically planned legislative activity [30]. Even though the scope of these evaluations was vast in coverage [29], the nearly identical results in this field obtained by Sweden and Spain in the cited report are solid foundations for the present comparative research.

\section{B. Research Framework}

A legal literature review, comprising both Acts, and their corresponding commentaries and pertinent legal materials for their correct interpretation, was conducted with the objective of determining whether the fractured exercise of GPP among Europe has been influenced by any legal elements.

The methodology consisted of four main steps (Fig. 1). The first step focuses on identifying the totality of the Directive's sustainability and environmental mentions throughout all procurement steps-illustrated in Fig. 1 as '(1)'-which have mostly resulted from a gradual accommodation of green concerns in public procurement and some highly influential European Court of Justice case law. ${ }^{7}$ The importance of '(1)', which subsumes the Directive's green considerations' articles, lies in the fact that they act as an enabler for GPP for all Member States [31].

The allocation of these green considerations among the rest of provisions of the Directive, alongside the content of EC (2018) report 'Public procurement guidance for practitioners' [32] procurement phases, is illustrated in Fig. 2. The pentagram, while excluding the aggregate of the Directive's Articles, does include only a representation of the most frequently used Articles of each phase, to show how the Directive's environmental provisions are integrated in the legal text and interact among other green and regular Articles.

The second step examines how '(1)' has been transposed by Spain and Sweden, consequently converting to '(1.a)' and '(1.b)'. LOU and LCSP have took on the entirety of the Directive's environmental considerations that are green pillars-located primarily in the definition of the subject-matter of the contract, the drafting of the technical specifications, the use of labels, qualification and exclusion, awarding of the contract, and performance conditions - in accordance with their corresponding principles ${ }^{8}$ and with their own particularities and additionalities.

The third step consists of the selection of which LOU and LCSP's Articles are most suitable to be examined, thus laying down a concrete framework for the analysis carried out in the fourth and final step.

For the choice of which of such LOU and LCSP's green articles were to be contrasted in this paper, we examined two benchmarks: the legal comparative methodology and previous literature findings on GPP analysis. It is sustained by some sectors of the doctrine that legal comparative research can be viewed as a method in its own right [33], and that

\footnotetext{
7 Significantly among many others, Case C-513/99, Concordia Bus Finland Oy Ab v Helsingin kaupunki and HKL-Bussiliikenne [2002] ECR I-07213; Case C-448/01, EVN AG and Wienstrom GmbH v Republik Österreich [2003] ECR I-14527; and Case C-368/10, European Commission v Kingdom of the Netherlands [2012] ECLI:EU:C:2012:243.

8 As remarked above, LOU stands by a voluntary approach in accordance with its Fourth chapter, Third section, and LCSP sets out in its Art 1.3. a mandatory approach.
} 
the comparison itself corresponds to the main purpose of the investigation [34]. Additionally, we have emphasized the analytical method, which aims to detect commonalities and dissimilarities in different legal systems, while using 'ideal types' - in this case, a high degree of effective environmental provisions - to grade those legal concepts pursuant to the degree of fitting such type [33].

As for the findings of previous literature covering a GPP analysis, Cheng et al. [35] discovered that some environmental considerations were more frequently and extensively utilized and discussed in academic literature than other considerations. Hence, step 3 comprised our detection of two different sets of Articles in LOU and LCSP: those adhering to the Directive's wording except for some slight nuances, and those presenting substantial differences in the drafting and inclusion of national legal figures. Then we selected, from the latter set of Articles, the most environmentally distinctive ones; the grounds for exclusion of suppliers, awarding criteria, and special conditions for performance, which in turn, according to Cheng et al. [35], were used in a limited manner to contribute to greening the contracts.

Finally, step 4 comprises a comprehensive study and analysis, available in the section below, of LOU and LCSP's Articles picked in step 3, in the light of LOU's preparatory works, which have a high value for the interpretation of legislation and are usually observed by the Swedish Courts as well, and LCSP's doctrine and specialists' commentaries, ${ }^{9}$ since in Spain preparatory works do not provide a significant insight for the Act [36].

\section{Results of the Comparative Analysis}

\section{Sweden and Spain's Procurement Acts}

\section{A. Transposition Process and Techniques}

The Swedish Government put forward in LOU preparatory works [37] that the legislative technique for the implementation of the Directive was to stay as closely as possible to its substance, wording, and structure [37], ${ }^{10}$ even though it admitted some exceptions by virtue of which LOU would provide further clarification or supplementary provisions on concrete aspects of the Directive [37]. Such a transposition style is a deviation from the historical Swedish model, which was based on a thorough review and major rewording of European directives before integrating them into Swedish legislation [36]. To uphold this shift, the Government invoked some strong and compelling motives, including, among others, avoiding potential legislative interpretation problems, ambiguities, and the uncertainty of an incorrect transposition of the Directive and its subsequent consequences, and easing the application of LOU [36].

The definitive version of LCSP also reflects a deviation, but in this case, away from the Directive. Its content is more extensive than the Directive's, encompassing other regulations applicable to public procurement, partly due to the Spanish traditional existence of a detailed specific public legislation of procurement prior to the existence of the procurement Directives. Moreover, the majority of the doctrine has noted LCSP's regulatory character

\footnotetext{
${ }^{9}$ Please note that most of the comments included in the section below come from an independent translation performed by the authors of this paper.

10 Section 5.1 Utgångspunkter för genomförandet.
} 


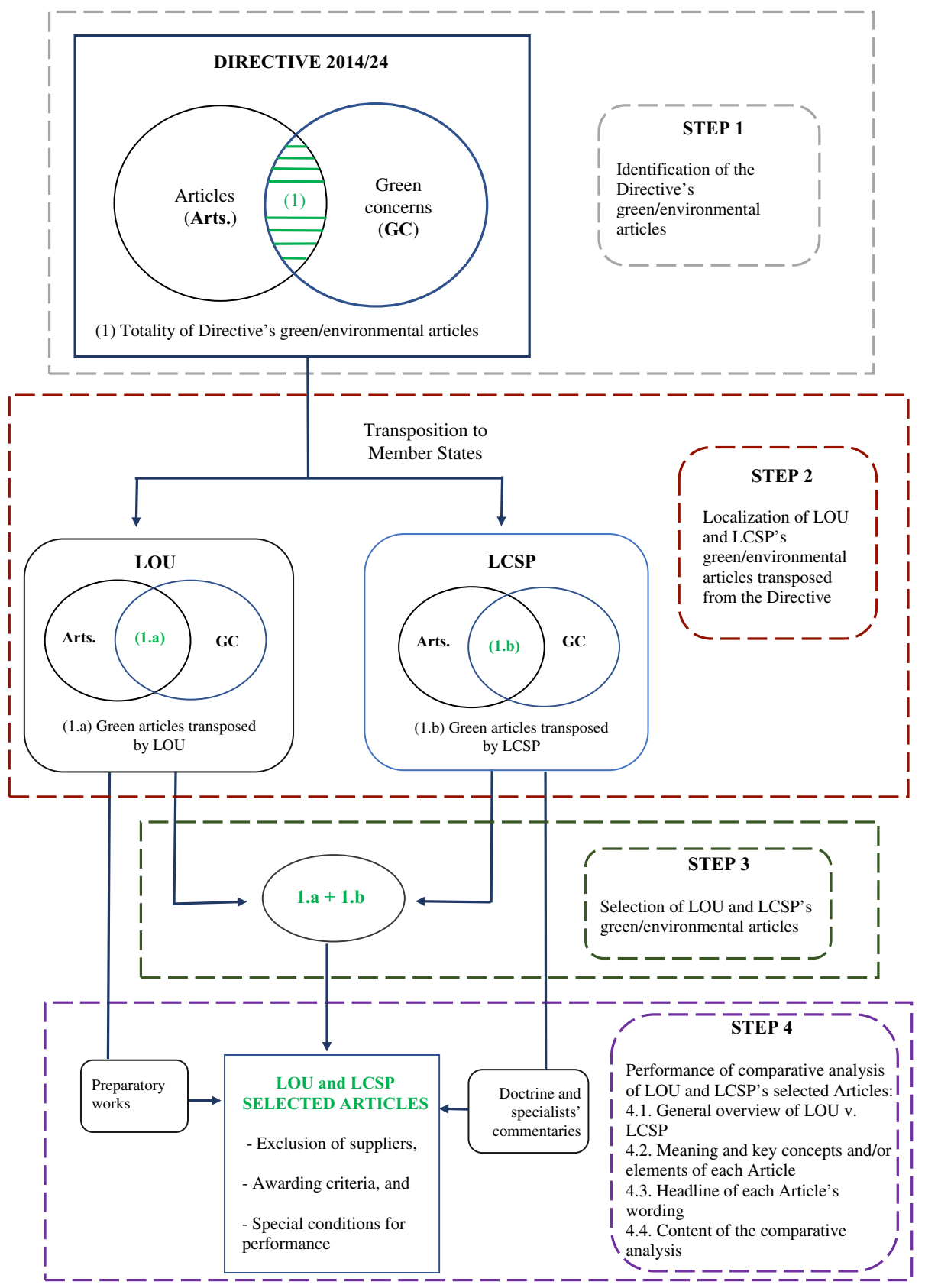

Fig. 1 Methodology of this research and legal comparative research study

and its dense configuration of the text, mostly comprised by excessively long and numerous precepts and cross references [36], which has resulted in both the establishment of more rigid provisions than the ones set out by the Directive and a prospective complication of its application [38-40]. 


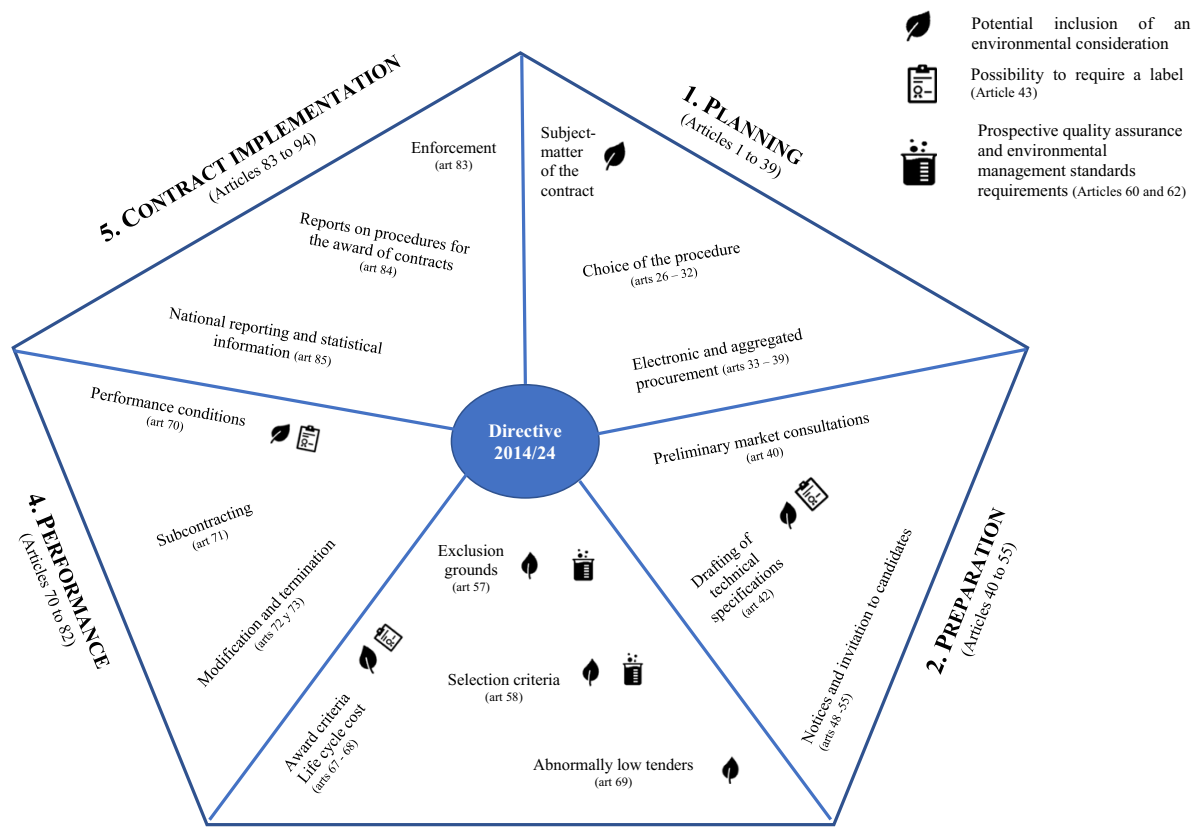

3. CHOICE OF PARTICIPANTS AND AWARD OF CONTRACTS (Articles 56 to 69)

Fig. 2 Legal representation of public procurement phases. The Results section is structured to follow key procurement considerations as outlined here

\section{B. Entry into Force, and Voluntary V. Mandatory Environmental Perspectives}

LOU came into force on 1 January 2017, ten months past the due date established in the Directive, as a consequence of a generally extensive Swedish legislative process, several deferments, and the Swedish Government's need to elaborate on the environmental (and social) protection of the draft bill, which was regarded insufficient during the public inquiry phase and constituted a key political issue for the Government throughout LOU's enacting [36].

Nevertheless, the Government promoted the voluntariness of the inclusion of environmental considerations [37] ${ }^{11}$ by maintaining the 'should-rule' or 'bör-regeln' —under which contracting authorities should take into account social and environmental horizontal policies when the nature of the procurement so justifies [27]—which has its origin on the (now repealed) previous Swedish Procurement Act [41], ${ }^{12}$ and was subsequently transferred to LOU.

Since its creation, the 'should-rule' has not been exempted from criticism. Back in 2009, the Swedish Agency for Disability Policy Coordination ${ }^{13}$ expressed their preference for a mandatory standard, the Swedish Board of Trade ${ }^{14}$ questioned foreign suppliers' viability to comply with this rule, and the Board of the Faculty of Law of Stockholm recommended

\footnotetext{
11 Section 9.3 Målsättningsbestämmelser om miljöhänsyn, sociala hänsyn och arbetsrättsliga hänsyn.

12 Chapter 1, section 9.a.

13 In Swedish language, Myndigheten för Handikappolitisk Samordning, Handisam.

14 In Swedish language, Kommerskollegium.
} 
an individualized assessment of which environmental requirements were the most appropriate to set in each procurement [42].

In the drafting process of LOU, the Swedish Competition Authority ${ }^{15}$ and the Council on Legislation ${ }^{16}$ enquired whether the 'should-rule' continued to be necessary, in view of the new light the Directive provided on environmental criteria. The Government responded affirmatively, arguing that its general scope of application in all phases of procurement, whether subject to the Directive or national legislation, serves a supplemental or additional role. In practical terms, such a role works in a similar fashion to a balance: an environmental obligation outweighs the 'should-rule', but if there is a lack of a mandate or provision in the applicable legislation, the 'should-rule' must be regarded [43]. ${ }^{17}$

LCSP delay was substantially longer than LOU's, being published on 9 November 2017 and entering into force four months later [28], ${ }^{18}$ due to the (legal) impossibility of the then interim Government to submit draft legislation to the Parliament [44], and subsequently by a vast submission of amendments to be discussed in Congress once the new Government took office [36, 39]. One of those discussions was the environmental approach in LCSP's Article 1.3, not initially within the LCSP draft, however subsequently unanimously approved [45]. This new section, which has gathered the approval of most of the doctrine, diverts from the Spanish repealed Act and the Directive by establishing the transversal and compulsory incorporation of social and environmental criteria in all procurement, provided that it is related to the object of the contract, and its inclusion is believed to provide a better value for money in contractual performance, as well as a greater and more efficient use of public funds. ${ }^{19}$

Article 1.3 LCSP has been vastly commented on from various perspectives. Gallego Córcoles [45] deems that the introduction of such compulsory provision was pertinent, in light of the confusing interpretation of the European Union's then new legal framework, and highlights that the central positioning of this Article confers solemnity to the overcoming of a public procurement exercise based merely on the economy. To this idea, Terrón Santos [46] adds that the instrument of transversality is interconnected to the nudge needed to extend the achievement of a mediate environmental purpose through public procurement to all LCSP aspects. Gimeno Feliu [39] remarks that this Article, which constitutes an evident advancement towards the abandonment of a formal bureaucratic view of procurement, establishes a strategic perspective as the core of public procurement, while including, at the same time, immediate references to social and environmental value.

\section{Selection of Articles}

\section{A. Grounds for Exclusion of Suppliers}

A procurement's best tender might not be ultimately awarded the contract if the bidder falls into the mandatory or voluntary exclusion grounds of the Directive. In this sense, a mandatory ground implies an immovable removal from the tender process, whereas an elective

\footnotetext{
15 In Swedish language, Konkurrensverket.

16 In Swedish language, Lagrådet.

17 Section 9.3.

18 LCSP, Final Provision 16.

19 Furthermore, this Art is complemented by the provision of Art 28.2 of the same Act, which asserts that public authorities and entities will positively value the incorporation of social, environmental and innovation consideration as positive aspects in public procurement.
} 
ground, qua a proved breach of environmental obligations, depends on the judgement of the contracting authority [24]. ${ }^{20}$ To examine whether a bidder should or not be excluded, the Directive clarifies that public authorities may study whether the bidder is unreliable, has questionable integrity, or has performed deficiently in a previous tender. Furthermore, the Directive also asserts that authorities should pay special attention to the principle of proportionality when considering an exclusion, as they will bear the responsibility of an erroneous decision [24]. ${ }^{21}$

LOU: A contracting authority may exclude a supplier from participation in procurement, if the authority can show that the supplier is in breach of applicable environmental obligations

Coherently with the LOU's transposition technique, the Directive's mandatory and voluntary exclusion provisions were implemented closely to the original wording and structure [27]. ${ }^{22}$ The adherence to this legislative formula was explicitly suggested by the Government $[37]^{23}$ after gathering LOU's deliberation process input and offers a focus on the elective removal due to an environmental breach.

A remarkable point of the discussions previous to settling on the wording of Chapter 13 Section 3 of LOU is the debate on the nature-mandatory or voluntary-that the exclusion for an environmental breach should assume. The Swedish Enforcement Authority ${ }^{24}$ and the Swedish Work Environment Authority ${ }^{25}$ endorsed a compulsory approach for the economic operators that infringe applicable environmental, social, and labour law obligations [37]. ${ }^{26}$ The motive why this proposal was not reflected in LOU is because of the Government's counterargument that testing these Authorities' thesis against the principle of proportionality resulted in an insufficient base for a compulsory removal, since such an intrusive decision cannot be taken on imprecise or vague indications [37].

LCSP: Whoever is subject to the following specific environmental breaches shall not be hired

Moving to LCSP, the exclusion grounds are translated into a 'hiring ban' [28]. ${ }^{27}$ The essence of this system is that only those economic operators who are not under a hiring ban will be able to be eligible in a tender. ${ }^{28}$ The function of this prohibition is that public authorities preventively avoid contracting with economic operators which have not performed dutifully, or which have engaged in reprehensible or negligent business behaviours [47].

A characteristic of this ban that makes LOU and LCSP diverge completely, is the lack of voluntary grounds for an exclusion, eradicated by the literality of Article 71: 'Economic operators subject to any of the following hiring bans shall not be able to contract...'.

\footnotetext{
${ }^{20}$ Article 57 covers the entirety of exclusion grounds, and its section 4.a) covers the elective environmental grounds.

21 Ibid, Whereas 101

22 Section 13 refers to exclusion of suppliers, and section 3.1 mentions a facultative exclusion due to an environmental breach.

23 Section 22.1.3 Uteslutning på grund av missförhållanden i övrigt.

24 In Swedish language, Kronofogden.

25 In Swedish language, Arbetsmiljöverket.

26 Concretely, The Swedish Enforcement Authority supported the conversion of Art 57(4) of the Directive to mandatory, and Swedish Work Environment Authority only advocated for the mandatory grounds of a breach of Art 18(2) of the Directive.

27 Art 71, Prohibiciones de contratar.

28 Additionally, suppliers also must comply with other eligibility conditions laid down in Art 65.1 LCSP.
} 
Referring solely to the prohibition to contract as a consequence of an environmental breach, LCSP requires, like Article 57.1 of the Directive, a conviction by a final judgement. Specifically, the inability to hire will derive from a final unappealable judgement for an environmental criminal offence $[28]^{29}$ and a final unappealable sanction for a serious environmental infringement in accordance with the applicable law [28]. ${ }^{30}$ The configuration of the sanctions that trigger the contracting ban has raised some criticism among the doctrine. Serna Bardavío [48] sustains that the fact that this Article required a serious infringement or minor breach for other non-environmental exclusion of an economic operator, degrades the protectionist green standards of this law.

\section{B. Awarding Criteria}

The awarding criteria have been pointed out as an opportunity to foster innovation and voluntary green performance improvements $[19,49]$ and as a promotion of CE through life-cycle cost provisions [46]. The Directive recognizes the importance of this phase and of presenting the corresponding provisions in a simple and streamlined way to the possible extent [24]. ${ }^{31}$

LOU: A contracting authority shall award a contract to the supplier with the tender that is most economically advantageous for the authority

Most of the specialized organs that participated in LOU's transposition did not agree that the award provisions were presented clearly in LOU's legislative proposal. For example, the Council on Legislation pointed out the unclear meaning of award criteria as well as their relationship with cost-effectiveness and life-cycle cost. In addition, the Council proposed to change the name of award criteria to evaluation of tenders or evaluation criteria, because it considered that award criteria and technical requirements could be confused if a comparison were to be made on how well both are met. The Government agreed on the inconsistent use of these terms in the Directive but defended that it was more appropriate to keep a Directive-like design in this Article [43]. ${ }^{32}$

LOU: Which tender is most economically advantageous shall be assessed based on:

best price-quality ratio, cost, or price

Another point of dissent between the Council on Legislation and the Government was the order of the most economically advantageous tender grounds listed in LOU's Chapter 16 Section 1. Unlike the Directive [24], ${ }^{33}$ LOU sorted the best price-quality ratio first, followed by cost and price. While the Council recommended a reverse order, the Government considered that this arrangement subtly highlights the best price-quality, conferring certain significance to it [37].

This attempt to accentuate evaluation grounds related to other than price and/or cost can contrast with LOU's lack of awarding environmental provisions or exemplary lists. Athwart the advice of the Swedish Environmental Protection Agency, which suggested that LOU

\footnotetext{
29 Art 71.1.a).

30 Art 71.1.b).

31 Whereas 89.

32 Section 25.1 Tilldelningskriterier vid offentlig upphandling och upphandling inom försörjningssektorerna. Furthermore, the proposal of some consultative bodies of employing only the concept of the most economically advantageous tender was disregarded for two reasons: increased difficulty for the application of LOU, and unclarity for the sustainability provisions.

33 Art 67.2 .
} 
should have stated that an award criterion could be an environmental function of a product or service, the Government believed that such possibility could be inferred from the corresponding provisions and the necessity of the link with the subject-matter of the contract, and that there were guidelines available for support and facilitating its application. This externalization of environmental exemplification was decided after the Government assessed the risks of insuperable legal technical difficulties and over-regulating LOU [37].

The last decision taken by the Government in relation to price was not to restrict the price or cost only as the sole award criterion, as permitted by the Directive. Jointly with other consultative bodies, the Government expressed that evaluating the basis or just price/ cost can still include quality demands in the procurement, by setting mandatory or high standard environmental technical requirements [37].

LOU: If a supplier's tender does not match the applicable environmental obligations, the authority may decide that the supplier shall not be awarded the contract

LOU's Chapter 16 Section 9 offers the possibility for the authorities to decide whether a supplier should not be awarded the contract, in the event that its tender does not match the applicable environmental obligations. ${ }^{34}$ Yet again, the Government's view of the wording and content of this Article collided with the rest of the consultative bodies' opinion. The Government described this provision as a safety valve [37], ${ }^{35}$ affirming that including this type of provision within the award phase - as well as interpreting it in the light of the principles of equal treatment and proportionality-leads to controlling the award to a supplier that has tender deficiencies throughout any phase of the tendering requirement, and that otherwise would be the winner of the bid [37].

The consultative bodies raised various comments: some ${ }^{36}$ rejected the inclusion of this Article, and the Swedish Procurement Authority ${ }^{37}$ welcomed a clarification of which situations would be affected by the provision, since it was believed that neither the Directive ${ }^{38}$ nor LOU provided guidance on how to interpret this section. Likewise, other authorities pointed out that any breach of the supplier's obligations pursuant to tendering phase would suffice to not award a contract to such bidder, and the law firm Delphi stressed that this provision was equivalent to over-regulating LOU [37].

LCSP: Contracts will be awarded by using a plurality of award criteria based on the most economically advantageous tender, to be determined by economic and quality criteria, being possible to include environmental considerations in the latter, for instance (...)

The notion of over-regulation can act as a connecting lead for LOU and LCSP. Contrary to LOU's structure and the arguments provided for its definitive wording, one of the most distinctive features of LCSP's Article $145^{39}$ - which gathered unanimous approval in Congress during its preparation [45]—is its exhaustive numerus apertus list of social and

\footnotetext{
34 As well as other social or labour law applicable obligations.

35 Ibid, section 25.4 Avstående från tilldelning i vissa fall.

36 Among others, the Swedish Work Environment Authority, which did support the mandatory exclusion of suppliers that breach environmental obligations (please refer to exclusion route map for a supplier's breach of environmental obligations above).

37 In Swedish language, Upphandlingsmyndigheten.

38 Art 56.1, third para.

39 On requisites and types of awarding criteria. The list of sustainable criteria is comprised within its section $2.1^{\circ}$.
} 
environmental quality criteria that may be used by contracting authorities to determine the most economically advantageous tender.

LCSP awarding process is based on criteria regarding the most economically advantageous tender, which will be evaluated in accordance with economic and quality criteria, the latter potentially comprising environmental or social aspects linked to the subject-matter of the contracts [28]. ${ }^{40}$ Besides, the quality criteria will have to be included along with a costrelated criterion [28]. ${ }^{41}$ Only if previously justified within the tender documents, the contract could be awarded by criteria based on cost-effectiveness on the basis of price or cost.

Despite LOU's and LCSP unique and unrelatable awarding provisions, LCSP's Article 145 has received a comparable criticism to LOU's. For instance, Carbonero Gallardo [50] holds the opinion that this Article is too extensive and not clear enough, resulting in excessively vague requirements and criteria, an unsystematic display of the sustainability criteria, and an indistinctive use of the new Directive's awarding concepts.

Indirectly, similarly to LOU's attempt to emphasize quality over price, LCSP use of several award criteria intends to avoid the prevalence of lowest price offers that affect the quality of the goods or services being procured [51]. Furthermore, LCSP prescribes to employ more than one award criteria for certain contracts, including those which performance could cause a significant impact in the environment [28]. ${ }^{42}$

LCSP: An award criterion shall be considered to be linked to the subject matter of the contract when (...)

LCSP instructions to assess whether an award criterion is linked to the subject-matter of the contract are also noteworthy. Beyond the Directive and LOU's corresponding provisions, ${ }^{43}$ Article 145.6 adds a particular focus on environmental, socially sustainable and fair processes of production, provision or trading of works, supplies, or services. A last relevant jurisprudential addendum to LCSP is the inadmissibility of requiring a general or particular environmental management system as an award criterion. Instead, such demand is only valid in the procurement selection phase, to determine the technical solvency of a bidder [52].

LCSP: A decision not to award or conclude the contract may only be taken for public interest reasons

The conditions detailed by LCSP to not award a contract — unlike LOU—do not carry environmental obligations, subordinating this contracting authority's decision to 'public interest reasons' duly justified in the tender documents [28]. ${ }^{44}$ In this event, if the alleged underlying reasons for not awarding the contract still subsist, it will not be possible to initiate a new procurement for the same subject-matter of that contract [28]. ${ }^{45}$ The broadness of such public interest reasons allows for viewing this Article in the light of the comments made to LOU's equivalent Article, which suggested a wider ground for not awarding a contract and reminded that no contract should be awarded if there were a breach of any applicable procurement obligations. This LCSP figure has been delimited by the jurisprudence and doctrine, which on a general level, have determined that contracting authorities that are

\footnotetext{
40 LCSP, Art 145.6.

41 LCSP Art 145.2 last para.

42 LCSP, Art 145.3.h).

43 Directive 2014/24/EU, Art 67.3 and LOU chapter 16 section 2 s para, respectively.

44 Art 152.3 .

45 Ibid.
} 
considering not awarding a contract have to observe administrative basic principles, e.g. efficiency and proportionality [53].

\section{Special Conditions for Performance}

Special performance conditions can be the most appropriate tool for the implementation of environmental policies, because they do not limit the competence or interfere in the contract's management, endeavour to provide quality to the contract [54], ${ }^{46}$ and are composed by fixed objective requirement(s) that have no impact on the assessment of the tenders $[24]^{47}$

LOU: A contracting authority may instate specific environmental conditions for contract performance

Likewise, LOU preparatory works state that whenever any contracting authority is debating whether to set a requirement as an award criterion or a performance condition, it must observe that award criteria do not offer any guarantee in terms of compliance [43]. ${ }^{48}$

LOU's Chapter 17 Section 1 was inherited from the previous, repealed Swedish procurement Act [27]. ${ }^{49}$ The main amendments were intended to adapt and update this provision to the Directive's requirements, and they include introducing the link to the subjectmatter of the contract and deciding not to include the exemplary list of provisions [43] available in the recitals of the Directive. ${ }^{50}$ Thus, LOU's preparatory works refer to such repealed Act and its corresponding works $[55]^{51}$ for the rationale for the environmental considerations [43].

Just as with the exclusion grounds and awarding criteria, there were suggestions for a mandatory implementation of special performance conditions. The Swedish Consumer Agency $^{52}$ believed that this approach was justified, and that the Government had carried out a specific inquiry. Nonetheless, this inquiry did not achieve the degree of necessary depth for the enforcement of a mandatory provision, and the provision was designed as close as possible to (now repealed) Directive 2004/18/CE [55].

The feedback on the compulsory proposal was mostly unfavourable. The Swedish Agency for Public Management ${ }^{53}$ supported the voluntariness of special performance conditions, affirming that a mandatory rule required an analysis as well as an impact assessment. The report drafted for estimating which environmental conditions were fit for application in procurement was described as difficult to understand by the Swedish Competition Authority, which held the opinion that it could create uncertainty among contracting authorities and complicate the procurement process.

Two more concerns involving procurement risks were brought up. In particular, the consultative bodies reflected that the lack of clear guidelines on the interpretation and application of environmental considerations could alienate the contracting authority's ability

\footnotetext{
46 In reference to Agreement 72/2016 by Aragón's Tribunal of Public Contracts, on socially responsible procurement.

47 Whereas 104.

48 Prop. 2015/16:195, section 26.1 Särskilda villkor för fullgörande av. kontrakt.

49 Chapter 6 section 13.

50 Whereas 97.

51 Section 10.3 Villkor för fullgörande av. kontrakt och om miljöhänsyn och sociala hänsyn.

52 In Swedish language, Konsumentverket.

53 In Swedish language, Statskontoret.
} 
to make business judgements. Subsequently, it was also noted that environmental performance conditions could increase the rate of incorrectly executed procurement and costly legal proceedings. The meaningfulness of these opinions resides in the subsistence nowadays of such risk-averse views on green procurement [25].

LCSP: In any case, at least one social or environmental special performance conditions among those listed below must be included in the tender documents

LCSP's Article detailing special performance conditions ${ }^{54}$ also has its origin in the Spanish repealed Procurement Act. ${ }^{55}$ But while the prior legislation established a voluntary incorporation of sustainability conditions, due to the lawmaker's will and the directions of Article 1.3 , it is currently mandatory to include at least one special performance condition (economic or innovation-related within the environmental or social field) from an exemplary list provided by the same Article. ${ }^{56}$ Even though this provision is a step towards a more sustainable public procurement, it is not a definitive push for greener purchases, since the contracting authority will have to decide which kind of special conditions are appropriate to include in view of the subject-matter of the contract [56].

LCSP: In particular, it will be possible to establish, among others, environmental considerations aimed at (...)

Another peculiar characteristic of such exemplary enumeration is that it is not composed of simple conditions, yet such requirements are intended to achieve a specific goal [57]. This illustrative green catalogue of purposes includes: reduction of greenhouse gas emissions, a promotion of sustainable water management, renewable energy, product recycling and reusable packaging, or the delivery of bulk products and organic production. Serna Bardavío [48] expressed that this enumeration is rather disorganised, almost as if the legislator arranged the entirety of this mechanism quickly and in one single provision. Meanwhile, Moreno Ibáñez [57] posed that the compulsory introduction of special performance conditions could be excessive, to the extent that it is a general compulsory requirement that does not take into consideration any measurable circumstance, not even the value of the contract.

LCSP: It will be possible to determine penalties in the tender documents (...)

Finally, in order to ensure the effective compliance of these special performance conditions [58], their breach can entail a different set of sanctions or penalties [28]. ${ }^{57}$ In the event of breach, the penalties have to be proportional to the seriousness of such breach, and each of them shall not exceed $10 \%$ of the price of the contract excluding VAT, nor the total sum exceed $50 \%$ of the price of the contract [50]. ${ }^{58}$ If the special performance conditions have been attributed the character of an essential contractual obligation, the contract could be terminated [28]. ${ }^{59}$ And, as advanced above, if the breach is not typified as a cause for termination of the contract, it could be classified as a serious infringement in the tender documents or in the contract. Consequently, provided that the supplier has acted with willful/

\footnotetext{
54 Art 202.

55 Real Decreto Legislativo 3/2011, de 14 de noviembre, por el que se aprueba el texto refundido de la Ley de Contratos del Sector Público, Art 118.

56 Art 202, section 1 last para and section 2.

57 Art 202.3.

58 Art 192.

59 Art 211.f).
} 
malicious intent or negligently, resulting with penalties or damages, this will result in a hiring ban for future procurements [28]. ${ }^{60}$

\section{Discussion and Conclusions}

\section{A. Main Findings of the Comparative Analysis}

Despite sharing the identical origin, LOU and LCSP are radically different. The most distinguishable features between the two Acts are their legislation technique and their environmental approach.

Whereas LOU preparatory works express the necessity to enact as closely to the Directive as possible among fears of over-regulation, LCSP has been described as complex and rigid and surpasses the Directive (and LOU) in terms of green considerations (for instance, the exhaustive exemplary lists or additional requisites on the award and special performance provisions).

On the other hand, LOU does not include any green mandatory stipulations, unlike LCSP, although this could be further nuanced. Numerous consultative bodies suggested or even demanded their inclusion during the preparation of LOU. While those have not been reflected in LOU's definitive wording, the Government has acknowledged some indirect mechanisms to enforce a level of coerciveness, such as the use of knock-out green technical requirements or the decision not to award upon an environmental breach. Furthermore, the Government also made active efforts to enhance the available greenness of LOU, for example, by altering the order of the most-advantageous tender.

LCSP is undoubtedly located in a higher step of environmental imperativeness than LOU, with its exclusion grounds and special performance conditions, and their corresponding sanctions. However, these configurations do not exempt LCSP from criticism. Some believe these measures are not enough, and others think they may be excessive or that their structure could be improved.

Regardless of all these disparities, there were a few common commentaries. Namely, the Directive's lack of guidance and indistinctive use of some terms, particularly in the awarding phase. Another recurring concern mentioned throughout LOU's preparatory works in the observations of the three Articles examined is the perception of GPP (and consequently $\mathrm{CPP}$ ) related to risk. Such risk is allocated across the entirety of the procurement process and gets translated into several barriers which still present challenges [58].

Foremost, CPP legal obstacles have to be highlighted: the complexity of relating the environmental criteria to the subject-matter of the contract, the technical issues of verifying the bidders' compliance with the green requirements, given that no official verification mechanisms have been established, the uncertainty of which criteria will effectively improve the environmental quality of the good, work or service procured [59], or the need to accurately monetising environmental aspects to meet with awarding and life-cycle cost requirements [60]. In regard to this last notion, Olsson and Öjehag-Pettersson [60] showed that this could mean that high costs of environmental degradation could be offset by low purchasing price.

Another remarkable impediment is the lack of an established definition of CPP. Given its relative novelty and the Directive's exclusive use of the term 'environmental', there is a

60 71.2.c). 
lack of precise understanding as to what CPP exactly entails in practice and how or when a tender can be deemed circular. The blurred distinction between GPP and CPP combined with risk-aversion from public authorities can culminate in the preference for integrating minimum criteria or continuing bare GPP under the new frame of CPP, while limiting the potential circularity of public procurement [21].

Moreover, the implementation of several predefined environmental criteria in procurement does not necessarily make the outcome of the procurement greener or circular. Likewise, there is no sufficient evidence on how well GPP criteria actually capture the circular elements [11]. Sönnichsen and Clement [19] argue that one of the best strategies to encourage circular procurement is active support from circular public procurement policies, which act as a strong facilitator, mandate and direction for managers; hence, the lack of clear CPP guidance in existing policies may have a cooling effect on decision-makers. On the contrary, Gallego Córcoles [45] defends that success of green measures does not solely rely on procurement laws, but also on the achievement of a proper performance and on a high political compromise. Still, our analysis demonstrates that current GPP regulations require better inclusion of $\mathrm{CE}$ elements to truly encourage a step from GPP to CPP.

\section{B. Future Trends and Policy Guidelines}

Our findings of the comparative analysis between LOU and LCSP show that, based on the similarities of some of the commentaries and suggestions raised from the evident disparities between both Acts, a clear European legal framework could address such disparities and level out GPP's uptake [25]. Moreover, further research is needed on how to develop a straightforward European legal framework for both GPP and CPP. It would be advisable that policy makers focus on the legal framework for public procurement by starting to map a transition to CPP by using the European GPP instruments currently available. For instance, one area of attention for policy making is life-cycle costing, as included in the Directive, LOU and LCSP. ${ }^{61}$ Another area is standardization and circularity metrics addressing all dimensions of CE: (1) material recirculation, (2) (re)utilization, and (3) longevity of products to ensure that materials are reclaimed from prior use phases, used intensely, and retain their value for as long as possible [61].

In Sweden, this could be achieved by developing a close collaboration between policy makers and macro-level authorities or bodies, such as the Delegation for Circular Economy (Delegationen för cirkulär ekonomi ${ }^{62}$ ), the National Agency for Public Procurement (Upphandlingsmyndigheten), and the Swedish Association of Local Authorities and Regions (Sveriges Kommuner och Landsting).

In Spain, the 'Spanish Circular Economy Strategy and Action Plan' [62] might be used to attain this purpose, notwithstanding the regional legislative competencies of the Autonomous Communities. Particularly, it would be also be advisable to strengthen the coordination between the competent legislative bodies as well as from the Government, since currently some GPP and CPP amendments are being implemented in LCSP through other Acts [63]. ${ }^{63}$

\footnotetext{
61 Article 68, Chapter 16 sections 4 and 5, and Article 148, respectively.

62 The Delegation was set up by the Swedish Parliament in 2018, Protocol 2018-04-12 M2018/01090/Ke. https://delegationcirkularekonomi.se/download/18.745dc19c170b0621a1f6e0/1583757800502/180412Inr\% C3\%A4ttandeavenDelegationf\%C3\%B6rcirkul\%C3\%A4rekonomi.pdf

${ }^{63}$ For example, via the recently passed Act 7/2021, of 20 of May, of climate change and energy transition, LCSP has been substantially amended in terms of the inclusion of new green requirements to comply with.
} 
Such a macro-level cooperation could influence regulations and CPP criteria in both Sweden and Spain, as well as facilitate implementation plans for both GPP and CPP so that (1) both the demand and supply of green/circular products is stimulated; and (2) procurement of works, functions, or other services can be done in ways that do not enforce the replacement of the required equipment while ensuring fair market competition at the same time.

Acknowledgements The authors wish to thank Professors Gerardo García-Álvarez and José María Gimeno Feliu from University of Zaragoza for their helpful comments and discussions around the study design.

Authors' Contributions All authors contributed to the study conception and design, which arose from Leticia Fuertes-Giné's PhD Law studies' research stay in RISE's Sustainable Business Unit, in which she collaborated with Emanuela Vanacore and Agnieszka D. Hunka in the project 'Realizing a Circular Economy in Society (RACES)'. Material preparation, data collection and analysis were performed by all authors. The first draft of the manuscript was written jointly (except for the legal analysis, which was prepared exclusively by Leticia Fuertes-Giné), and all authors commented on previous versions of the manuscript. All authors read and approved the final manuscript.

Funding Open access funding provided by RISE Research Institutes of Sweden. This study was financially supported by the Swedish Research Council for Sustainable Development (FORMAS) under the Project Number 2019-02235.

Availability of Data and Material Not applicable.

Code Availability Not applicable.

\section{Declarations}

Conflicts of Interest/Competing Interests The authors declare that they have no known conflict of interest that are relevant to the content of this article.

Ethics Approval Not applicable.

Consent to Participate Not applicable.

Consent for Publication Not applicable.

Open Access This article is licensed under a Creative Commons Attribution 4.0 International License, which permits use, sharing, adaptation, distribution and reproduction in any medium or format, as long as you give appropriate credit to the original author(s) and the source, provide a link to the Creative Commons licence, and indicate if changes were made. The images or other third party material in this article are included in the article's Creative Commons licence, unless indicated otherwise in a credit line to the material. If material is not included in the article's Creative Commons licence and your intended use is not permitted by statutory regulation or exceeds the permitted use, you will need to obtain permission directly from the copyright holder. To view a copy of this licence, visit http://creativecommons.org/licenses/by/4.0/.

\section{References}

1. Nikolaou IE, Jones N, Stefanakis A (2021) Circular economy and sustainability: the past, the present and the future directions. Circ Econ Sustain 1:783-783. https://doi.org/10.1007/s43615-021-00054-9

2. Korhonen J, Honkasalo A, Seppälä J (2018) Circular economy: the concept and its limitations. Ecol Econ 143:37-46. https://doi.org/10.1016/j.ecolecon.2017.06.041

3. Klein N, Ramos TB, Deutz P (2021) Advancing the circular economy in public sector Organisations: employees' perspectives on practices. Circ Econ Sustain. https://doi.org/10.1007/s43615-021-00044-x 
4. European Commission (2020) Communication from the Commission - a new circular economy action plan. For a cleaner and more competitive Europe

5. Saidani M, Yannou B, Leroy Y, Cluzel F, Kendall A (2019) A taxonomy of circular economy indicators. J Clean Prod 207:542-559. https://doi.org/10.1016/j.jclepro.2018.10.014

6. Azevedo S, Godina R, Matias J (2017) Proposal of a sustainable circular index for manufacturing companies. Resources 6(4). https://doi.org/10.3390/resources6040063

7. Di Maio F, Rem PC (2015) A robust Indicator for promoting circular economy through recycling. J Environ Prot 06(10):1095-1104. https://doi.org/10.4236/jep.2015.610096

8. Figge F, Thorpe AS, Givry P, Canning L, Franklin-Johnson E (2018) Longevity and circularity as indicators of eco-efficient resource use in the circular economy. Ecol Econ 150:297-306. https://doi.org/ 10.1016/j.ecolecon.2018.04.030

9. Pauliuk S (2018) Critical appraisal of the circular economy standard BS 8001:2017 and a dashboard of quantitative system indicators for its implementation in organizations. J ResConRec 129:81-92. https://doi.org/10.1016/j.resconrec.2017.10.019

10. European Commission (2017) Public procurement for a circular economy. Good practice and guidance. https://ec.europa.eu/environment/gpp/pdf/Public_procurement_circular_economy_brochure.pdf. Accessed 2 Jan 2022

11. Alhola K, Ryding SO, Salmenperä H, Busch NJ (2018) Exploiting the potential of public procurement: opportunities for circular economy. J Ind Ecol 23(1):96-109. https://doi.org/10.1111/jiec.12770

12. Bouwer M, de Jong K, Jonk M, Berman T, Bersani R, Lusser H, Nissinen A, Parikka K, Szuppinger P (2005) Green public procurement in Europe. Status overview. Virage Milieu and Management. https:// ec.europa.eu/environment/gpp/pdf/Stateofplaysurvey2005_en.pdf. Accessed 2 Jan 2022

13. Renda A, Pelkmans J, Egenhofer C, Schrefler L, Luchetta G, Selçuki C (2012) The uptake of green public procurement in the EU27. DG Environment. In. College of Europe and Centre for European Policy-studies-(CEPS),-Study-FWC-B4/ENTR/08/006. https://ec.europa.eu/environment/gpp/pdf/ CEPS-CoE-GPPMAINREPORT.pdf. Accessed 2 Jan 2022

14. Smol M (2021) Inventory and comparison of performance indicators in circular economy roadmaps of the European countries. Circ Econ Sustain. https://doi.org/10.1007/s43615-021-00127-9

15. European Union, Consolidated Version of the Treaty on the Functioning of the European Union (2012) OJ C326/47, Art.-288. https://eur-lex.europa.eu/LexUriServ/LexUriServ.do?uri=CELEX:12012E/ TXT:en:PDF. Accessed 2 Jan 2022

16. European Commission (2021) Why public procurement is important. https://ec.europa.eu/growth/single-market/public-procurement_en. Accessed 2 Jan 2022

17. Oficina Independiente de Regulación y Supervisión de la Contratación (2020) Informe Anual de Supervisión-de-la-Contratación-Pública-de-España-(in-Spanish). https://www.hacienda.gob.es/RSC/ OIReScon/informe-anual-supervision-2020/ias-2020.pdf. Accessed 2 Jan 2022

18. Töyrä A, Doherty A, Hammargren G, Bern A-B, Morild K, Pyk L (2019) Statistik om offentlig upphandling 2019. Upphandlingsmyndigheten Rapport 2019:5, Konkurrensverket Rapport 2019:3.240-(in-Swedish). https://www.upphandlingsmyndigheten.se/globalassets/dokument/publi kationer/statistikrapport_2019_webb.pdf. Accessed 2 Jan 2022

19. Sönnichsen SD, Clement J (2020) Review of green and sustainable public procurement: towards circular public procurement. J Clean Prod 245. https://doi.org/10.1016/j.jclepro.2019.118901

20. Alhola K, Salmenperä H, Ryding S-O, Busch NJ (2017) Circular public procurement in the Nordic countries. TemaNord Nordic Council of Ministers, Copenhagen. https://doi.org/10.6027/ TN2017-512

21. Kristensen HS, Mosgaard MA, Remmen A (2021) Circular public procurement practices in Danish municipalities. J Clean Prod 281. https://doi.org/10.1016/j.jclepro.2020.124962

22. Lăzăroiu G, Ionescu L, Uță C, Hurloiu I, Andronie M, Dijmărescu I (2020) Environmentally responsible behavior and sustainability policy adoption in green public procurement. Sustainability 12(5). https://doi.org/10.3390/su12052110

23. Directive 2004/18/EC of the European Parliament and of the Council of 31 March 2004 on the coordination of procedures for the award of public works contracts, public supply contracts and public service contracts (2004). OJ L134/114. https://eur-lex.europa.eu/legal-content/EN/TXT/ PDF/?uri=CELEX:32004L0018\&from=en . Accessed 2 Jan 2022

24. Directive 2014/24/EU of the European Parliament and of the Council of 26 February 2014 on Public Procurement and repealing Directive 2004/18/EC (2014). OJ L94/95. https://eur-lex.europa.eu/ legal-content/EN/TXT/PDF/?uri=CELEX:32014L0024 . Accessed 2 Jan 2022

25. Mélon L (2020) More than a nudge? Arguments and tools for mandating green public procurement in the EU. Sustainability 12(3). https://doi.org/10.3390/su12030988 
26. Pollitt C, Bouckaert G (2017) Public management reform. A comparative analysis - into the age of austerity, 4th edn. Oxford University Press

27. Lagen (2016:1145) Om Offentlig Upphandling (2016) (in Swedish) https://rkrattsbaser.gov.se/sfst? bet=2016:1145-(official-Englishtranslation) https://www.konkurrensverket.se/globalassets/dokum ent/informationsmaterial/rapporter-och-broschyrer/informationsmaterial/swedish-public-procu rement-act.pdf . Accessed 2 Jan 2022

28. Ley 9/2017, de 8 de noviembre, de Contratos del Sector Público, (2017) BOE-A-2017-12902 (in Spanish). https://www.boe.es/buscar/act.php?id=BOE-A-2017-12902 . Accessed 2 Jan 2022

29. European Commission (2018) Directorate-General for Employment, Social Affairs and Inclusion, Palaric, E., Thijs, N., Hammerschmid, G., A comparative overview of public administration characteristics and performance in EU28, Publications Office. https://data.europa.eu/doi/10.2767/13319 . Accessed 2 Jan 2022

30. Gimeno Feliu JM, Amoedo-Souto CA (2018) Estudio sistemático de la Ley de Contratos del Sector Público. Aranzadi Thomson Reuters (in Spanish)

31. Romera BM, Caranta R (2017) EU public procurement law: purchasing beyond Price in the age of climate change. Eur Procure Public Priv Partnersh Law Rev 12(3):281-292. https://www.jstor.org/ stable/26695464. https://doi.org/10.21552/epppl/2017/3/10. Accessed 2 Jan 2022

32. European Commission (2018) Directorate-general for regional and urban policy, public procurement: guidance for practitioners on the avoidance of the most common errors in projects funded by the European structural and investment funds, publications Office. https://data.europa.eu/doi/10. 2776/461701. Accessed 2 Jan 2022

33. Van Hoecke M (2015) Methodology of comparative legal research. LaM. https://doi.org/10.5553/ $\mathrm{rem} / .000010$

34. Hage J (2014) Comparative law as method and the method of comparative law. Maastricht European private law institute working paper no 2014/11. https://doi.org/10.2139/ssrn.2441090

35. Cheng W, Appolloni A, D'Amato A, Zhu Q (2018) Green public procurement, missing concepts and future trends - a critical review. J Clean Prod 176:770-784. https://doi.org/10.1016/j.jclepro. 2017.12.027

36. Treumer S, Comba M (2018) Modernising public procurement. The Approach of EU Member States. Edward Elgar Publishing

37. Regeringens proposition 2015/16:195, Nytt regelverk om upphandling (2015) (Prop 2015/16:195) (in Swedish) https://www.regeringen.se/rattsliga-dokument/proposition/2016/06/prop.-201516195/ Accessed 2 Jan 2022

38. Baño León JM (2018) La Ley de Contratos del Sector Público y gestión de lo público. ¿Regulación o sobrerregulación? Monografías de la Revista Aragonesa de Administración Pública XVIII:9 ISSN 1133-4797 (in Spanish)

39. Gimeno Feliu JM (2019) La Ley de Contratos de Sector Público 9/2017. Sus principales novedades los problemas interpretativos y las posibles soluciones Aranzadi Thomson Reuters (in Spanish)

40. Spanish council of state, Expert Opinion 1116/2015 (2016) (in Spanish) https://www.boe.es/buscar/ doc.php?id=CE-D-2015-1116. Accessed 2 Jan 2022

41. Lagen (2007:1091) Om Offentlig Upphandling [2007], as amended by Lag om ändring i lagen (2007:1091) om offentlig upphandling, (SFS 2010:571) (in Swedish) https://www.riksdagen.se/sv/ dokument-lagar/dokument/svensk-forfattningssamling/lag-20071091-om-offentlig-upphandling _ sfs-2007-1091. Accessed 2 Jan 2022

42. Regeringens proposition 2009/10:180, Nya rättsmedel på upphandlingsområdet (2010) (in Swedish) https://www.regeringen.se/rattsliga-dokument/proposition/2010/04/prop.-200910180/\#: : text=F\%C3\%B6rslageninneh\%C3\%A5llerbest\%C3\%A4mmelserombl,f\%C3\%B6rslagenipropositio nenskainf\%C3\%B6ras . Accessed 2 Jan 2022

43. Prop. 2015/16:195, section 9.3 Målsättningsbestämmelser om miljöhänsyn, sociala hänsyn och arbetsrättsliga-hänsyn-(in-Swedish) https://www.regeringen.se/49f178/contentassets/5cc3302198 594030a4c0a75cff492da2/nytt-regelverk-om-upphandling-del-1-av-4-kapitel-1-21-prop.-20151 6195 . Accessed 2 Jan 2022

44. Ley 50/1997, de 27 de noviembre, del Gobierno (1997) BOE-A-1997-25336 (in Spanish) https:// www.boe.es/buscar/act.php?id=BOE-A-1997-25336 . Accessed 2 Jan 2022

45. Gallego Córcoles MI (2017) La integración de cláusulas sociales, ambientales y de innovación en la contratación pública. Documentación Administrativa (4). https://doi.org/10.24965/da.v0i4.10497 (in Spanish)

46. Terrón Santos D (2019) La nueva actividad pública de fomento: el «green nudge» en la actual contratación pública. Gestión y Análisis de Políticas Públicas:24-39. https://doi.org/10.24965/gapp. i22.10597 (in Spanish) 
47. Aymerich Cano C (2019) Las prohibiciones para contratar en la Ley de Contratos del Sector Público de 2017. Revista Aragonesa de Administración Pública 53:306-343 ISSN 1133-4797 (in Spanish)

48. Serna Bardavío D (2018) Mecanismos para la protección del medio ambiente en la nueva Ley de Contratos del Sector Público. Monografías de la Revista Aragonesa de Administración Pública XIX:117-139, ISSN 1133-4797 (in Spanish)

49. Backes C (2017) Law for a circular economy. Publishing EI (ed) Utrecht Centre for Water Oceans and Sustainability law (UCWOSL) and University of Utrech, The Netherlands

50. Carbonero Gallardo JM (2019) El test de los criterios de adjudicación. Gabilex (Revista del Gabinete Jurídico de Castilla-La Mancha II (Un año de compra pública con la LCSP 2017):40 ISSN 2386-8104 (in Spanish)

51. Villarejo Galende H, Calongue Velázquez A (2018) Las principales novedades de la nueva Ley 9/2017, de 8 de noviembre, de Contratos del Sector Público. Revista Jurídica de Castilla y León 46:58, ISSN 1696-6759 (in Spanish)

52. García-Álvarez G (2018) El papel de los mecanismos de mercado en la protección ambiental. Monografías de la Revista Aragonesa de Administración Pública XIX:9-5, ISSN 1133-4797 (in Spanish)

53. Gris González JC (2016) La renuncia a la celebración del contrato y el desistimiento del procedimiento de adjudicación por la Administración: jurisprudencia y doctrina. Cuadernos de derecho local 40:201-217 ISSN 1696-0955 (in Spanish)

54. Gimeno Feliu JM (2020) La visión estratégica en la contratación pública en la LCSP: hacia una contratación socialmente responsable y de calidad. Revista de Economía Industrial 415:89-97 ISSN: 0422-2784 (in Spanish)

55. Regeringens proposition 2006/07:128, section 10.3 Villkor för fullgörande av kontrakt och om miljöhänsyn-och-sociala-hänsyn-https://www.regeringen.se/contentassets/9fb0e $2 \mathrm{f} 23 \mathrm{bc} 441 \mathrm{~d} 9918 \mathrm{f}$ a5469475abe2/prop.200607128-ny-lagstiftning-om-offentlig-upphandling-och-upphandling-inomomradena-vatten-energi-transporter-och-posttjanster (in Swedish). Accessed 2 Jan 2022

56. de Guerrero Manso C (2018) La inclusión de condiciones especiales de ejecución como medida efectiva para la defensa del medio ambiente a través de la contratación pública. Revista Aragonesa de Administración Pública Número extra 19:141-177, ISSN 1133-4797 (in Spanish)

57. Moreno Ibáñez I (2019) Las condiciones especiales de ejecución en la Ley de Contratos del Sector Público. Contratación administrativa práctica: revista de la contratación administrativa y de los contratistas 164: 39, ISSN 1579-3036 (in Spanish)

58. Moreo Marroig T (2018) La ejecución del contrato tras la entrada en vigor de la Ley 9/2017. Revista Española de Control Externo XX(60):219-258 ISSN 1575-1333 (in Spanish)

59. Pérez de los Cobos Hernández E (2020) La contratación pública ecológica como instrumento de impulso de la economía circular. Actualidad Jurídica Ambiental 2(102):677-691 ISSN-e 19895666 (in Spanish)

60. Olsson D, Öjehag-Pettersson A (2020) Buying a sustainable society: the case of public procurement in Sweden. Local Environ 25(9):681-696. https://doi.org/10.1080/13549839.2020.1820471

61. Boyer RHW, Mellquist AC, Williander M, Fallahi S, Nyström T, Linder M, Algurén P, Vanacore E, Hunka AD, Rex E, Whalen KA (2021) Three-dimensional product circularity. J Ind Ecol. https:// doi.org/10.1111/jiec. 13109

62. Government of Spain, Ministry for the Ecological Transition and the Demographic Challenge, https:// www.miteco.gob.es/es/calidad-y-evaluacion-ambiental/temas/economia-circular/estrategia/ (in Spanish). Accessed 2 Jan 2022

63. Sanz Rubiales Í (2018) La protección del ambiente en la nueva ley de contratos: del Estado meramente «comprador» al Estado «ordenador». Revista de Administración Pública 205:49-80. https://doi.org/10. 18042/cepc/rap.205.02 (in Spanish) 